\title{
The Image of Modern Woman in A.S. Laksana's Bidadari yang Mengembara Short Story
}

\author{
Deny Gunawan Susandi \\ Ilmu Susastra (Sastra), Department. Susastra \\ Faculty of Humanities, UniversitasIndonesia \\ Depok,Indonesia \\ Syarif Hidayatullah State Islamic University \\ Jakarta Indonesia \\ deny.gunawan72@ui.ac.id
}

\begin{abstract}
This study focuses on the character analysis a masseuse whosename is Nita in "Bidadari Yang Mengembara" short story. Itaims to show how Nita described as a modern woman but at the same timefitsto the figure of a common traditional Javanese women. Qualitative method and feminist literary critics are used in this study. The findings reveal that as a modern woman, Nita dares to oppose the values that should be obeyed by women in general. However, the story also reveal that a woman cannot entirely escape from the general gender image which is in subordinate position.
\end{abstract}

Keywords-Culture; Gender; Feminism Approach; Feminist Literary Critics

\section{INTRODUCTION}

Bidadari Yang Mengembara is a short story that has been published by two publishers, Kata Kita (2004) and Gagas Media (2014). It is one of the short stories collection books with the same title. This short story is written by A.S. Laksana who known as the best literary author of Tempo magazine in 2004 and 2013. The short storynarrated a masseuse woman who goes around the village to find a customer. One day, she gave her massage service to a man, Alit, with a tremendous pain in his chest. She helped that man to heal the pain for six days. They became intimate and Alit gave her the name Nita. When Alitfinally regained his health, he disappeared.

Nita thencontinued her job as a masseuse. From one of her female customer, she got information where Alit was. But she gave false location to Nita. The female customer who is also the narrator of the story did this to keep Nita from losing hopein finding where Alit is.

In connection with this, I wantto analyze how Nita, as a woman is described as having the freedom to work, looking for the man she likes, and proving that she is different from common figure of a masseuse.

This study is a study of literary works which related to women or study that examine the figures or female characters in a short story. To discuss this issue, feminism approach is the most suitable approach to be used in this study [1, p. 5]. The writer also uses the feminist theory in this study and focus on "feminine" which deals with culturally defined characteristics [2, p. 144].

\section{METHOD}

The method which is used in this research is qualitative research. Qualitative research is a study that is focused on collecting different types of materials by literature study, text analysis, and cultural production[3, p. 5]. For this study, the material or text used is a short story.

This study also uses feminist literary criticism as the theory which in its development is relating to how culture provides a position to women. This is because literature, culture, and criticism are interrelated and cannot be separated (Wellek, René and Austin Warren, 2014, 34-43). It relates to what Plain and Sellers[4, p. 2] said that feminist literary criticism can be distinguished from feminist political activism and social theory. Since the second wave of feminist movement in 1960s, the struggle for women equal rights was increased[5, p. 24]. The goal in this movement is growing towards the oppression of women in social life and gives effect to the development of feminist literary criticism[6, p. 3]; [2, p. 143].

Violence, exploitation, marginalization, powerlessness, and cultural imperialism are kind of oppression which often happens in our life[7, pp. 37-63]. As well as the form of oppression that often appears in literary works, literary authors, today, have begun to fight against it. In some literary works, female characters are written in an unusual position and role. This is the condition where women are complaining the inequality of man-made laws[8, p. 18]. For example is a woman who has a role as a hero and has a more crucial role than a man in a movie that I've discussed in previous research [9].

Then, will it work? Yes, it will. The efforts in shaping the "contrary" women character will certainly affect the way of social life view against women. Tong [10, p. 40] quotes in Feminist Though what Jean Bethke Elshtain wrote in her critique "Why Can't a Woman Be More Like a Man?" that women can become like men if they set their minds to it. For literary works, how the woman's character thinks, behaves, and shows her feminist values really depends on whether the author wants to raise it up or not.

Moreover, something that should be underlined is gender perspective and stereotype occurs because it is shaped, socialized, strengthened, and even socially constructed[11, p 40] [10, p. 103]. So, in this study it is important to see how the author describes the figure of Nita the masseuse as a form of the image of modern women who "break" the traditional cultural stereotype down and her "gender relation" (Flax, in Nicholson, ed., 1990 40; Humm in Wiyatmi, 1986, 22).

\section{RESULT AND DISCUSSION}

In "Bidadari Yang Mengembara" short story, the author did 
not tell explicitly about the origin of the masseuse. But we can identify itfrom narration and conversations between masseuse and other characters in thestory.

First, Nita's profession as a masseuse fits the characteristic of a Javanese woman. Her job is closely related to the culture and history of Java. It can be proven by observing the reliefs of the 8th-9th century BC in Borobudur and Prambanan temples. The reliefs described the king and queen who were massaged by his ladies/ dayang-dayang which show that Javanese women do have massage skills [12, p. 55].

\section{"Aku dan Daryono berpelukan di tengah kamar yang} berkabut...” [7, p. 23].

"Dalam hati aku sangat berterima kasih kepadanya karena ia menyamarkan nama Alit dan memberikan kepada temanku itu sebuah nama baru...” [7, p. 23]

From the quotation above, I know if the masseuse started calling Alit as Daryono then the narrator, as a massage customer, starts to know about Alit's new nickname.

Second, Nita - the masseuse - hides Alit's name to everyone, including the woman who in this story acts as a narrator, with the name Daryono. In this case, certainly not by chance Nita using the name Daryono to replace the original name Alit. Even, well-known figures in Indonesia who have the name Daryono are native Javanese. Such as Yono Daryono, a figure in Central Java; Iqbal Aji Daryono, an author of "Out of The Truck Box"; Daryono Hadi Tjahjon, a professor at ITB, Bandung; and the last is Daryono, the Indonesian footballer who is now playing forPersija.

As for her appearances, Nita is depicted as a middle age woman (forty two years old). She has a physical deficiency in her face.

"mendengar ucapan Alit, tukang urut itu, seorang perempuan empat puluh dua tahun dengan tulang hidung yang meleset, seperti diingatkan pada sesuatu” [7, p. 18]

"koin-koin receh di saku celana komprangnya berkerincang-kerincing setiap kali ia mengayunkan batang kaki" [7, p. 26]

She is also described as a poor woman. It can be assumed by the tinkling sound of coins from her pocket as she walked. Since she only has coins, Nita can be identified as a wong cilik because she earns low income in the village (Suseno 11).

"perempuan itu lewat di kampungku, suatu hari, mengenakan baju warna tanah dan celana komprang hijau lumut" [7, p. 22]

The text above is the narration that is spoken by the narrator when she saw Nita walking then sat down under the tree. The color of the clothing worn by Nita is not the color that women generally favor (such: pink, purple, baby blue, and yellow). But, the color selection (the upper part is brown and the bottom is green) can also be identified as traditional Javanese clothing-which is identical with batik. But the researcher cannot identify like that because batik that usually worn by women is not unusual if paired with a pants-shaped komprang.

From the analysis above, the researcher concluded that the masseuse, named Nita, is a 42 years old woman that looks like a Javanese woman with a very unfeminine look and a face with a broken nose. But the researcher still cannot say if she is really a Javanese woman. This is because the author of this short story does not give or show enough evidence that she is a Javanese woman. From the economic level viewpoint, if associated with Javanese culture, Nita belongs to the lower class or commonly called wongcilik.

Since women are fighting for their freedom, the goal of the feminist movement is not only to the equality in politics. However, women also need an opportunity to improve their economies in order to be fully liberated [10, p. 23]. This is depicted by the figure of Nita who chose to work as a masseuse rather than sit quietly at home and waiting for a man to come to her home to propose her. Nita is a woman figure often depicted in literary fiction works in the 19th century where under certain condition and pressed by the need that she has to work [2, p. 144].

"Aku yakin suatu hari akan kutemukan pahlawanku”, katanya. "sebab akulah sempalan tulang rusuknya dan ia menyebutku bidadari" [7, p. 26]

The quotation above is the Nita assertion that she will continue looking for Alit, wherever it will take her away.

The short story author puts Nita as an active figure. This position can place Nita as a subject who pursuing her object, as well as showing Nita's view that she is a female character who opposes the condition where men as subjects/masters; women as objects which is also radical-cultural feminists' views on sexuality [10, p. 66]. Actually, Nita can take the decision to accept the circumstances that Alit left her and choose nrimo like the nature of Java society in general. But she chose to wander to findhim.

From the analysis above, the researcher concluded that the masseuse, named Nita, is depicted as an image of a figure that fought for her rights as fought for by feminist movement figures. The struggle is not only in terms of just getting freedom. But also has focused on freedom of getting a job (economy) and looking for love. These evidence strengthening the argue that actually woman is not weak and the position of woman is not in inferior [13, p. 13].

Nita chases Alit, of course, because she feels confident to do so. The confidence feel that comes to Nita cannot be separated from how Nita is praised by Alit when Alit is in a faint position. She is portrayed as beautifully as an angel by Alit that makes her no longer care about her assumptions about her face before she is praised by Alit [14, p. 272].

"Bidadariku," kembali Alit berbisik. perempuan itu menangis. [7, p. 20]

"sebab akulah sempalan tulang rusuknya dan ia menyebutku bidadari" [7, p. 26]

In addition, Nita's hope grew when they were making love even though Alit is in unconsciousness condition. What both of them did together certainly made Nita, rationally, more confident that Alit is the man who loves her [8, p. 16]. The sex situation can be understood in the following quotation:

"Suhu tubuh keduanya meningkat beribu derajat. Keringat yang keluar dari tubuh mereka berubah menjadi uap.

Kamar berkabut. Pekat,'[7, p. 21] (Laksana, 2014, 21)

Nita conditions that feel there is a bond with a man after having sex is same as how the character Pariyem in lyrical prose books titled Pengakuan Pariyem (Linus, 2009) which seems to have a bond with a son of her employer named Den Bagus after having sex. Then, the researcher associates the character of nita with Pariyem figure because both of them are at the lower class level of society.

Furthermore, after falling in love with Alit because of what he said and what both of them did, Nita decided to pursue his love even though Alit had avoided her by moving to another place and did not tell Nita where he want to go. This is shown in the story when the narrator said "ketika sudah berhasil meredakan rasa perihnya, ia melanjutkan perjalanan dengan sisa tangis yang merintih-rintih" [7, p. 26] in the end of the 
story.

From the analysis above, the researcher concluded that the masseur, named Nita, is depicted as a woman who is different from other women. This is because Nita has a will to oppose the culture and find the person she loves even though it can make her hurt. Is it wrong? No, that is because actually woman ruled in the private sphere [8, p. 18]. And as long as Nita hasn't meet with Alit or married yet, Nita will always search her love and feel that her life is not yet complete [15, p. 306].

As a character that appeared as a freedom fighter, Nita was depicted still occupy an inferior position. Nita cannot conceal her shame and her sense of inferiority towards her imperfect physical condition. Her embarrassment due to her physical deficiency was raised in her conversation with Alit.

"Tapi tak pernah ada lelaki yang mau mengawiniku karena hidungku ringsek” [7, p. 19].

A woman's beauty can help her to marry the man that she wants. [5, p. 5]. Then, what Nita said above really illustrates that Nita feel insecure and threatened by the beauty of other women because of physique has shortcomings and assume that it is the reason why no man wants to propose to her (Saraswati, 2017, 204-206).

"Bahkan kalaupun kau berbohong tentang alamat itu, aku tetap mencatatnya sebagai sebuah kebaikan,” katanya.

"setidaknya, kau mencoba menyalakan harapan di jantungku dengan memeberikan alamat itu”, [7, p. 25]

Furthermore, Nita is also described as a woman who is too hopeful with a man who has left her. This is reflected in her dialogue with a narrator. Alit who abandoned Nita without any word can be identified as a man's consciousness of the superiority of women in which men's negative attitudes to women are actually a form of compensation from the inferiority complex which suffered by men[13, p. 37] .

\section{Conclusion}

Nita, the masseur, is identified as a woman who is able to break down a woman's culture that is always subordinated by men and dares to fight for the freedom right. The freedom here is not just a political issue like the main objective of the feminist movement, but also how the right to work and seek love is obtained by her. However, the figure of Nita also cannot be separated from the position of women who continue to be described inferior or positioned as subordinate of the female character.

This short story confirms that it is difficult for women to be entirely free from the shadows of men, no matter how strong she is and how free she is, the woman still in subordinate position to the man. It is seen from how, overall, Nita, who looks free in pursuing her love, is just like being fooled into looking for a man who, of course, is not the only one in the world. Nita, as a woman trying to show her freedom, actually reinforces the notion that women are on the inferior side and men stay on the superiorside.

\section{REFERENCES}

[1] Asean Spa Services Standard. Jakarta. Indonesia: ASEAN Secretariat, 2016.

[2] P. Barry, Beginning Theory: An introduction to literary and cultural theory. Manchester: Manchester University Press, 2013.

[3] S. Djajanegara, Kritik Sastra Feminis: Sebuah Pengantar. Jakarta: Gramedia Pustaka Utama, 2000.

[4] M. Humm, Feminism: A Reader. London: Routledge, 1992.

[5] M. Hunter, Race, Gender, and the Politics of Skin Tone. New York: Routledge, 2005.
[6] L. Jumarani, The Essence of Indonesian Spa: Spa Indonesia Gaya Jawa dan Bali. Jakarta: Gramedia Pustaka Utama, 2009.

[7] A. S. Laksana, Bidadari Yang Mengembara. Jakarta: Gagasmedia, 2014.

[8] S. Mendus, Feminsim andEmotions. London: Macmillan Press Ltd, 2000 .

[9] G. Plain and S. Sallers, A History of Feminist Literary Criticism. Cambridge: Cambridge University Press, 2007.

[10] R. Tong, . Feminist Thought: A More Comprehensive Introduction. Colorado: Westview Press, 2009.

[11] S. Santana K, Menulis Ilmiah: Metodologi Penelitian Kualitatif (Edisi Kedua). Jakarta: Yayasan Pustaka Obor Indonesia, 2010.

[12] C. A. Setyanti, "Pijat, 'Seni' Penyembuh Tertua untuk Stres dan Lelah," 25-Feb-2017. [Online]. Available: https://www.cnnindonesia.com/gayahidup/20170225073958-255-196091/pijat-seni-penyembuh-tertua-untukstres-dan-lelah/1.

[13] J. Suprana, Kelirumologi Genderisme. Jakarta: elex media komputindo, 2014.

[14] N. Wolf, The Beauty Myth: How Images of Beauty Are Used Against Women. New York: Harper Collins, 2008.

[15] A. Triatnawati, "Konsep dadi wong menurut wanita jawa.," Humaniora, vol. 17 , pp. $300-311,2005$. 